Abstract—Available tag-recapture and population genetics data for cobia (Rachycentron canadum) in the southeastern United States were evaluated to provide information on population structure and determine the geographic boundary between stocks in the Gulf of Mexico and the Atlantic Ocean. The movements of 1750 cobia were evaluated on the basis of assigned tagging and recapture zones. Genetic samples from an additional 2796 cobia collected during the presumed spawning season were genotyped at 10 microsatellite loci, and standard population genetic statistical analyses were applied to the resulting sample data set. Tag-recapture results indicate that cobia tagged south of Cape Canaveral, Florida, primarily move between that area and the Gulf of Mexico and that cobia tagged north of Georgia have little interaction with the area south of Cape Canaveral. Cobia tagged at Cape Canaveral distributed widely throughout the entire southeastern coast of the United States. Genetic analysis results agree, indicating separate stocks that occur from Texas through Hobe Sound on the east coast of Florida and from Savannah, Georgia, to the Chesapeake Bay in Virgina, with distinct genetic groupings within the Atlantic Ocean stock. The results indicate a transition area that occurs from Cape Canaveral through northern Georgia, and additional data from this region are necessary to further refine the stock boundary.

Manuscript submitted 5 November 2018. Manuscript accepted 13 August 2019. Fish. Bull. 117:220-233 (2019).

Online publication date: 23 August 2019. doi: 10.7755/FB.117.3.9

The views and opinions expressed or implied in this article are those of the author (or authors) and do not necessarily reflect the position of the National Marine Fisheries Service, NOAA.

\title{
Evaluation of the stock structure of cobia (Rachycentron canadum) in the southeastern United States by using dart-tag and genetics data
}

\author{
Matt Perkinson (contact author) ${ }^{1}$ \\ James Franks ${ }^{2}$ \\ Tanya Darden ${ }^{1}$ \\ Maggie Jamison ${ }^{1}$ \\ Read Hendon ${ }^{2}$ \\ Matt J. Walker ${ }^{1}$ \\ Susanna Musick ${ }^{3}$ \\ Michael R. Denson ${ }^{1}$ \\ Eric S. Orbesen ${ }^{4}$ \\ Email address for contact author: perkinsonm@dnr.sc.gov \\ ${ }^{1}$ Marine Resources Research Institute
South Carolina Department
of Natural Resources
217 Fort Johnson Road
Charleston, South Carolina 29412
${ }^{2}$ Gulf Coast Research Laboratory
University of Southern Mississippi
703 East Beach Drive
Ocean Springs, Mississippi 39564
}

The cobia (Rachycentron canadum) is a large, migratory pelagic species found throughout most of the world's tropical and subtropical waters, with the exception of the eastern Pacific Ocean (Shaffer and Nakamura, 1989). In the United States, the species is found throughout the Gulf of Mexico (GOM) and Atlantic Ocean from Texas through Massachusetts (Briggs, 1960), although catches north of the Chesapeake Bay in Virginia are less frequent. Life-history characteristics differ between cobia from the GOM and those from the western North Atlantic Ocean, with a faster growth rate in the GOM and a greater maximum age in the Atlantic Ocean (Burns et al. $\left.^{1}\right)$. In the GOM, cobia undertake

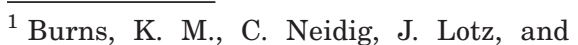
R. Overstreet. 1998. Cobia (Rachycentron canadum) stock assessment study in the Gulf of Mexico and in the South Atlantic. Mote Mar. Lab. Tech. Rep. 571, 108 p.
} [Available from website.] seasonal migrations from overwintering grounds in South Florida to spawning grounds in the northern GOM during spring and summer (Burns and Nei$\mathrm{dig}^{2}$; Ditty and Shaw, 1992; Biesiot et al., 1994; Franks and Brown-Peterson, 2002; Dippold et al., 2017), although some cobia may migrate from deeper offshore overwintering grounds to coastal areas as well (Hendon and Franks ${ }^{3}$ ). In the western North Atlantic Ocean, cobia enter high-salinity estuaries as well as nearshore locations in Georgia, South

\footnotetext{
$\overline{2}$ Burns, K. M., and C. L. Neidig. 1992. Cobia (Rachycentron canadum), amberjack (Seriola dumerili), and dolphin (Coryphaena hipurus) migration and life history study off the southwest coast of Florida. Mote Mar. Lab. Tech. Rep. 267, 58 p. [Available from website.]

${ }^{3}$ Hendon, J. R., and J. S. Franks. 2010. Sport fish tag and release in Mississippi coastal waters and the adjacent Gulf of Mexico, $13 p$. Final Rep., Proj. F-132, Segments 7-9. Gulf Coast Res. Lab., Univ. South. Miss., Ocean Springs, MS. [Available from website.]
} 
Carolina, North Carolina, and Virginia as water temperatures approach $20^{\circ} \mathrm{C}$ (Richards, 1967; Smith, 1995; Lefebvre and Denson, 2012). The results of work that involved the collection of eggs and larvae, as well as ovarian histology, indicate that spawning occurs in these inshore locations during the spring and summer (Smith, 1995; Franks and Brown-Peterson, 2002; Lefebvre and Denson, 2012), although spawning may also occur with fish aggregating on the continental shelf (Hassler and Rainville, 1975). When estuarine and nearshore waters drop below $20^{\circ} \mathrm{C}$ in the fall, cobia move out of these areas, although overwintering locations are not well known. Because cobia are a popular target for recreational anglers throughout their range, state and federal regulations have been established to promote sustainable fishing.

Formal management measures for cobia in the United States began with the implementation of the coastal migratory pelagic resources fishery management plan (FMP) in 1983 (GMFMC and SAFMC, 1983), which established a single stock of cobia extending from Texas through the border of North Carolina and Virginia (later extended through New York) and established a size limit of $838 \mathrm{~mm}$ fork length (FL). Management authority was shared by the Gulf of Mexico and South Atlantic Fishery Management Councils. In 2012, Amendment 18 to the FMP (GMFMC and SAFMC, 2011) established GOM and Atlantic Ocean migratory groups of cobia. Although early genetic analysis revealed no differences between GOM and western North Atlantic Ocean cobia (Hrincevich, 1993), differences in life-history characteristics, such as maximum age and growth rate, required the change. The stock boundary was established in Monroe County, Florida, at the current demarcation of jurisdiction between the management councils. The Monroe County stock boundary was chosen on the basis of the documented seasonal migration of GOM cobia from overwintering grounds in the Florida Keys to the northern GOM and the presumption that Atlantic Ocean migratory group cobia overwinter in the Florida Keys as well (Williams, 2001). Initial genetic and conventional tagging data analyzed in preparation for Southeast Data, Assessment, and Review 28 (SEDAR, 2013a, 2013b) refuted the Florida Keys as an overwintering location for western North Atlantic Ocean cobia and, as a result, Amendment 20B to the FMP (GMFMC and SAFMC, 2014) established a new boundary between GOM and western North Atlantic Ocean stocks at the border of Georgia and Florida. Data that led to the new stock delineation are presented herein.

Identification of fish stocks is necessary to properly allocate catch among multiple user groups and effectively manage the species under the requirements of the Magnuson-Stevens Fishery Conservation and Management Act (MSFCMA, 2007). Successful stock delineation is also critical to the stock assessment process, as most population models assume that the stock will have homogeneous life-history characteristics and a closed life cycle in which recruitment occurs from within that stock (Cadrin et al., 2005). Because these characteristics differ between GOM and western North Atlantic Ocean cobia, an appropriate delineation of the stock boundary is essential to accurately assigning life-history parameters such as growth rate, fecundity, and age structure for each stock. Stock identification methods include analyzing a variety of characteristics, such as meristics, reproduction, morphometrics, otolith composition and shape, parasite tags, and fatty acid profiles (Hilborn and Walters, 1992; Izzo et al., 2017); however, mark-recapture and genetic analysis are 2 of the most commonly used methods of identifying stocks.

Mark-recapture methods that involve external tags have been used for over a century to provide information on fisheries (Ricker, 1948). Tagging studies have been used to determine migratory patterns and stock structure of species such as the Atlantic salmon (Salmo salar) (Hansen and Jacobsen, 2003), billfish (Istiophoridae) (Orbesen et al., 2008), Queensland school mackerel (Scomberomorus queenslandicus), Australian spotted mackerel (S. munroi) (Begg et al., 1997), and pollock (Pollachius virens) (Neilson et al., 2006). In contrast to the use of tag-recapture methods in studies of stock structure, the use of genetic analysis in stock identification is a relatively recent and rapidly evolving field. Over the last 2 decades, genetic methods have been more frequently employed to distinguish population structure of fish; genetic analyses have included the use of random amplified polymorphic DNA in species such as the striped bass (Morone saxatilis) (Bielawski and Pumo, 1997), Pacific cod (Gadus microcephalus) (Saitoh, 1998), and Antarctic toothfish (Dissostichus mawsoni) (Parker et al., 2002). More recently, microsatellite markers have been used to differentiate stock structure in Atlantic cod (Gadus morhua) (Knutsen et al., 2011), steelhead (Oncorhynchus mykiss) (Campbell et al., 2012), and eulachon (Thaleichthys pacificus) (Flannery et al., 2013). Our study combined the more traditional tag-recapture analysis with modern genetic methods.

Preliminary genetic and tag-capture analyses of cobia stock structure in the southeastern United States conducted in preparation for the 2012 benchmark stock assessment (Perkinson and Denson ${ }^{4}$; Darden ${ }^{5}$ ) cast doubt on the accepted stock boundary in the Florida Keys. Recently, Dippold et al. (2017) examined cobia migratory patterns by using tag-recapture data; however, the study focused primarily on 5 zones within the GOM. All regions north of the Florida Keys were combined into a single zone, making a thorough evaluation of the stock boundary delineation between the GOM and Atlantic Ocean stocks difficult. To identify the most biologically appropriate delineation, we conducted a meta-analysis of all available tag-recapture data, adding additional zones to the east coast of Florida to provide greater resolution of movement. Additionally, we analyzed microsatellite genetic data from cobia to compare the genotypes of fish collected in locations throughout the GOM and western North Atlantic Ocean. Our combination of data sources provided a complementary

\footnotetext{
${ }^{4}$ Perkinson, M., and M. Denson. 2012. Evaluation of cobia movements and distribution using tagging data from the Gulf of Mexico and South Atlantic coast of the United States. SEDAR28-DW05, 17 p. Southeast Data Assessment and Review (SEDAR), North Charleston, SC. [Available from website.]

${ }^{5}$ Darden, T. 2012. Cobia preliminary data analyses-US Atlantic and GOM genetic population structure. SEDAR28-DW01, 2 p. Southeast Data Assessment and Review (SEDAR), North Charleston, SC. [Available from website.]
} 
approach to stock boundary identification (Begg and Waldman, 1999) with results that are more robust than those from the use of either method alone.

\section{Materials and methods}

\section{Tagging methods}

Tag-recapture data for cobia from 7 tagging programs were included in the analysis: the Virginia Game Fish Tagging Program, North Carolina Division of Marine Fisheries, South Carolina Department of Natural Resources (SCDNR), Hilton Head Reef Foundation, NOAA Southeast Fisheries Science Center Cooperative Tagging Center, Mote Marine Laboratory, and the Sport Fish Tag and Release Program of the Gulf Coast Research Laboratory, University of Southern Mississippi (Table 1). All 7 programs employed similar methods, including the use of nylon or stainless-steel-tipped dart tags and reliance on a trained group of recreational anglers and charter boat captains to tag and release cobia. Anglers were asked to submit a data card for each tagged fish that included the following information: tag number, date, release location, fish length (converted to millimeters in FL where necessary), and weight (converted to kilograms), as well as other pertinent information that differed by tagging program. Upon recapture of a tagged fish, anglers reported similar data, including whether the fish was released or harvested. In this study, we determined general migratory trends over a large geographic area on the basis of recapture data. There were minor differences in tag types (stainless versus nylon anchors) and incentive structure between programs and within programs during different time periods that could affect tag retention and reporting rates and could, therefore, influence estimates of mortality or other quantitative measures. However, these difference are unlikely to influence the analysis of large-scale migratory patterns based on capture and recapture location. Therefore, recapture data were pooled into a comprehensive data set. Tag and recapture locations were assigned a GPS coordinate on the basis of location description, if latitude and longitude were not otherwise provided. In those instances, we assigned latitudes and longitudes by using the best available information. These coordinates were assigned solely for the purpose of graphical depiction of recapture locations and not for analyses; all analyses were based on zone assignment. Only cobia at large for greater than $30 \mathrm{~d}$ were included in the final analysis to minimize the location bias of fish that were tagged and immediately recaptured. Where programs reported total length (TL), rather than FL of fish tagged, the formula $F L=13.52399+(0.878671 \times T L)($ SEDAR, 2013b) was used to transform data.

\section{Data partitioning}

Tagging areas and recapture areas were partitioned into 10 different zones for analysis of movement patterns (Fig. 1). The East Coast of the United States north of Florida was

\section{Table}

Number of cobia (Rachycentron canadum) tagged and recaptured by each of 7 tagging programs throughout the Gulf of Mexico and Atlantic Ocean off the southeastern United States between 1988 and 2017. The tagging programs were those of the following organizations: Virginia Game Fish Tagging Program (VGTP), North Carolina Division of Marine Fisheries (NCDMF), South Carolina Department of Natural Resources (SCDNR), Hilton Head Reef Foundation (HHRF), NOAA Southeast Fisheries Science Center (SEFSC), Mote Marine Laboratory (MOTE), and Gulf Coast Research Laboratory, University of Southern Mississippi (GCRL).

\begin{tabular}{lrrcc}
\hline $\begin{array}{l}\text { Data } \\
\text { source }\end{array}$ & $\begin{array}{c}\text { Number } \\
\text { tagged }\end{array}$ & $\begin{array}{c}\text { Number } \\
\text { recaptured }\end{array}$ & $\begin{array}{c}\text { Recapture } \\
\text { rate }(\%)\end{array}$ & $\begin{array}{c}\text { Years } \\
\text { active }\end{array}$ \\
\hline VGFTP & 3899 & 433 & 11.1 & $1995-2017$ \\
NCDMF & 73 & 5 & 6.8 & $\begin{array}{c}2017 \\
\text { SCDNR }\end{array}$ \\
1194 & 216 & 18.1 & $1990-2014$ \\
HHRF & 95 & 14 & 14.7 & $2007-2012$ \\
SEFSC & 1557 & 159 & 10.2 & $1986-2014$ \\
MOTE & 920 & 100 & 10.9 & $1991-2001$ \\
GCRL & 18,129 & 1197 & 6.6 & $1988-2017$ \\
Total & 25,867 & 2124 & 8.2 & $1986-2017$ \\
& & & &
\end{tabular}

segmented into 5 zones: the areas within and extending offshore of states north of Virginia, Virginia, North Carolina, South Carolina, and Georgia. All tagging and recapture events that occurred within the Chesapeake Bay were assigned to the Virginia zone. Because preliminary genetic results $\left(\operatorname{Darden}^{5}\right)$ indicated a break along the east coast of Florida, the area was segmented into 3 zones: north of Brevard County, encompassing the area from the Florida-Georgia border south to the border of Volusia and Brevard Counties; Brevard County, including Cape Canaveral; and south of Brevard County, encompassing the area from the border of Brevard and Indian River Counties to Biscayne Bay. County lines were chosen because of their congruency with recreational and commercial catch data used in the stock assessment process. To the south, the Florida Keys zone covered the area from Biscayne Bay around to Marco Island in southwest Florida. Although genetic structure and movements of fish between locations in the GOM to the Atlantic Ocean were evaluated, specific movements of fish solely within the GOM were beyond the scope of this paper, resulting in the entire GOM from Marco Island to the Texas-Mexico border being assigned a single zone. Dippold et al. (2017) provide a thorough analysis of cobia movements within the GOM. Analyses of movement between zones as well as recaptures within a zone were largely qualitative and focused on identifying seasonal trends and broad patterns in movement that indicate potential breaks in biological stocks.

\section{Genetics}

The SCDNR Genetic Tissue Collection currently houses more than 5050 archived genetic samples of cobia collected by numerous researchers and anglers around the 


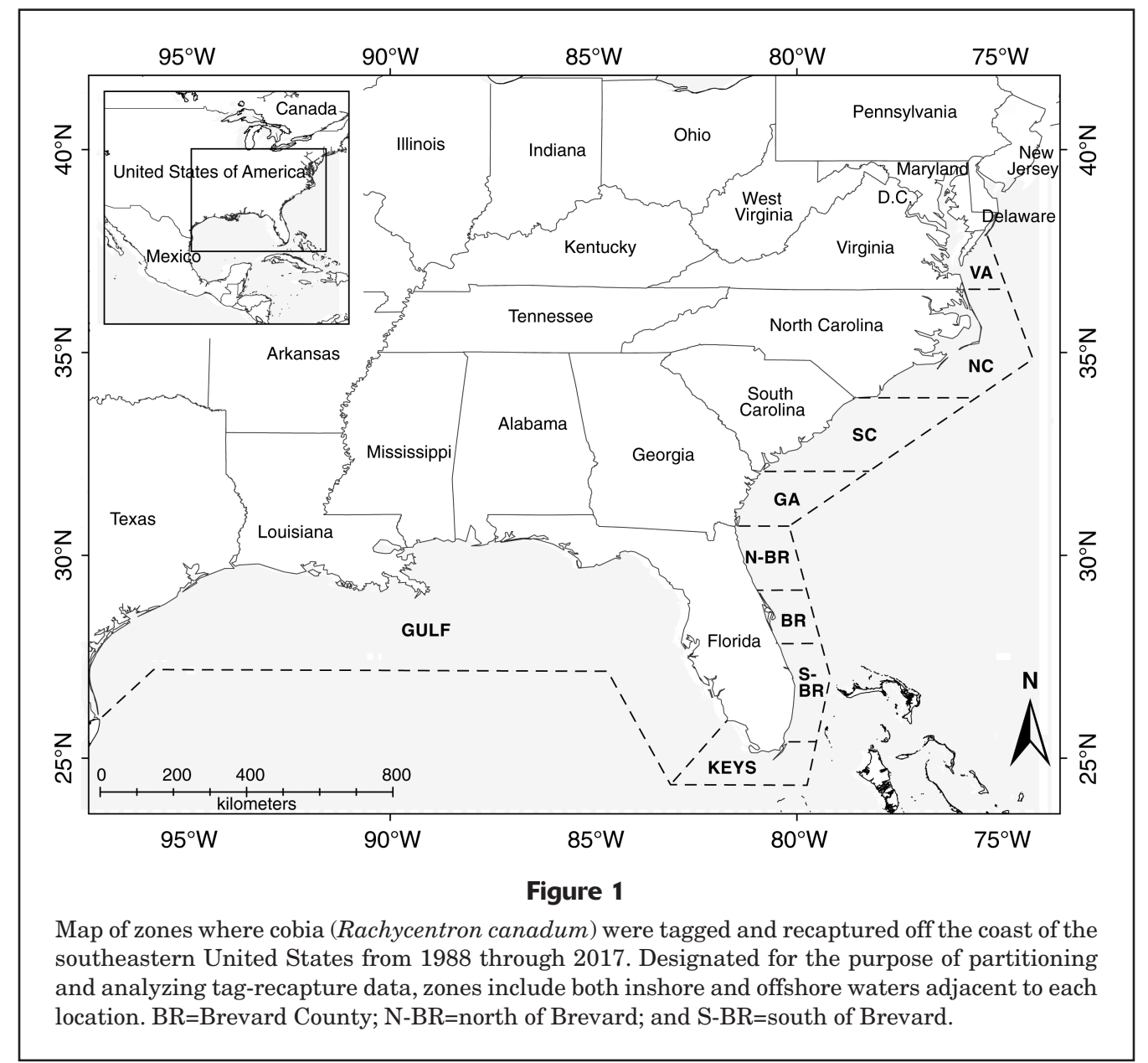

globe. In all cases, small tissue samples were collected from the anal or caudal fin and stored in either 95\% non-denatured ethanol (EtOH) or a sarkosyl-urea preservation solution ( $8 \mathrm{M}$ urea, $1 \%$ sarkosyl, $20 \mathrm{mM}$ sodium phosphate, $1 \mathrm{mM}$ EDTA) until processed. For the current project, sample selection included those collected along the U.S. coast in the GOM and western North Atlantic Ocean during cobia spawning season defined by each state on the basis of temperature-based patterns and gonadosomatic indices (SEDAR, 2013b). Available samples ranged from Virginia south along the Atlantic coast around the Florida peninsula into the GOM and westward to Texas. Spawning season was defined for each state in this way: Virginia, June-August; North Carolina, May-July; South Carolina and Georgia, April-July; Florida, March-August; Mississippi, May (only samples available); and Texas, April-August.

The sarkosyl-urea preservative simultaneously stabilizes sample DNA and serves as a preliminary cell lysis solution. The EtOH-stored samples were subjected to a proteinase K cell lysis prior to DNA isolation. All DNA isolation, microsatellite amplification, and genotyping methods followed the method of Darden et al. (2014). Briefly, DNA was isolated from all samples by using a magnetic bead isolation procedure. Ten polymorphic microsatellite loci were then amplified through polymerase chain reaction (PCR) in 3 multiplexed groupings. These loci have been optimized and multiplexed previously and were used to document both global and local population structure in cobia. PCR was conducted in $11-\mu \mathrm{L}$ reactions with 1× 5PRIME ${ }^{6}$ HotMaster buffer kit (5PRIME HotMaster Taq DNA Polymerase and 10× 5PRIME HotMaster Buffer, $5000 \mathrm{U}[5 \mathrm{u} / \mathrm{\mu L}]$; Qiagen Beverly, Inc., Beverly, MA) and with $2.5 \mathrm{mM} \mathrm{Mg}^{2+}, 0.2 \mathrm{mM}$ dNTPs, 0.3 units 5PRIME HotMaster Taq DNA Polymerase, $0.5 \mathrm{mM} \mathrm{MgCl}, 0.20 \mathrm{mg} / \mathrm{mL}$ BSA, $0.3 \mu \mathrm{M}$ forward and reverse primers, and $1 \mu \mathrm{L}$ of $1: 10$ diluted DNA template. Individual primer concentrations differ among loci and are given in Darden et al. (2014). Forward primers for all loci were labeled with WellRED fluorescent dyes (Beckman Coulter, Inc., Fullerton, CA). Thermal cycling for PCR used a modified $60^{\circ} \mathrm{C}$ touchdown protocol (Renshaw et al., 2006) consisting of an initial denaturation step at $94^{\circ} \mathrm{C}$ for $2 \mathrm{~min}$, followed by 34 cycles of denaturing at $94^{\circ} \mathrm{C}$ for $30 \mathrm{~s}$, annealing at $60^{\circ} \mathrm{C}, 57^{\circ} \mathrm{C}$,

\footnotetext{
${ }^{6}$ Mention of trade names or commercial companies is for identification purposes only and does not imply endorsement by the National Marine Fisheries Service, NOAA.
} 
and $54^{\circ} \mathrm{C}(7,7$, and 20 cycles, respectively) for $1 \mathrm{~min}$, and extension at $64^{\circ} \mathrm{C}$ for $2 \mathrm{~min}$, followed by a final extension step at $64^{\circ} \mathrm{C}$ for $60 \mathrm{~min}$ (as in Darden et al., 2014). Both size standards (GenomeLab DNA Size Standard Kit 400, Beckman Coulter, Inc.) and reaction products were separated with a Beckman Coulter CEQ 8000 Genetic Analysis System, with fragment size analysis performed with CEQ 8000 software. All chromatograms were scored manually by 2 independent readers. Discrepancies between readers were resolved in conference, or samples were rerun to obtain an unambiguous genotype for all individuals.

In 2004, researchers at SCDNR began a cobia stock enhancement research program, releasing discrete numbers of cobia juveniles into the wild. Therefore, all hatchery-produced fish were removed from the data set prior to further analysis. We used a maximum likelihood parentage approach as implemented in the software Cervus, vers. 3.0.3 (Kalinowski et al., 2007), to provide a statistical evaluation of parentage taking into account mutation rates, population allele frequencies, and lab error rates. The power of the loci suite to correctly identify hatchery fish as well as individual fish is high, with average parent-pair and identity non-exclusion probabilities of $1.7 \times 10^{-7}$ and $7.8 \times 10^{-12}$, respectively, indicating very low probabilities of incorrectly identifying hatchery fish or individuals. Parentage simulations (number of simulations $[n]=20$ ) were run with known sex parentage analysis by using allele frequencies from individuals collected from 2007 through 2009 ( $n=1407)$. All simulations were conducted with 10,000 offspring, 8 candidate parent pairs (with all parents sampled), 95\% genotyping, and low mistyping error (0.01) and mutation $(0.001)$ rates. Critical delta scores were determined by using $99.0 \%$ and $99.9 \%$ confidence levels for the relaxed and strict criteria, respectively. Parentage analyses for the juvenile samples were conducted with the modal simulation file from the simulation runs. All parental assignments were designated at the strict confidence level (99.9\%).

All remaining individuals that were successfully genotyped at 8 or more loci were subjected to sibship analyses as implemented in the software COLONY, vers. 2.0.6.4 (Jones and Wang, 2010), to identify any potential large family groups within the data set that could confound further genetic structure analyses. Two simulations were run by using settings of polygamous breeding, weak prior, updating allele frequencies, no genotyping error, and full likelihood and pairwise likelihood combined method for a medium run length. Any identified duplicate samples were removed from the data set prior to further analyses. Results were evaluated for consistency among runs for individual fullsib relationships as well as family sizes present.

For the initial analyses, the data set was partitioned into 18 geographic sections based on natural latitudinal breaks in the collection data (Table 2, Fig. 2). Standard population genetic statistical analyses were applied to the resulting sample data set. Population genetic structure throughout the collection range was assessed through evaluations of Hardy-Weinburg equilibrium (HWE) in GenAlEx, vers.
6.5 (Peakall and Smouse, 2006, 2012), analysis of molecular variance (AMOVA) in Arlequin, vers. 3.5.1.2 (Excoffier and Lischer, 2010), pairwise $F_{\mathrm{ST}}$-style statistics calculated in GenAlEx and Arlequin, and the clustering algorithms implemented in STRUCTURE, vers. 2.3.4 (Pritchard et al., 2000 ). Iterative AMOVAs $\left(R_{\mathrm{ST}}\right.$-based) were conducted to evaluate areas of genetic discontinuity in the data set with potential location groupings under 2- and 3-population scenarios. Pairwise comparisons of sample locations and HWE were conducted initially at the smallest geographic scale, and locations were combined sequentially to represent the smallest number of homogenous groupings. Estimates of $R_{\mathrm{ST}}, F_{\mathrm{ST}}, G_{\mathrm{ST}}, G_{\mathrm{ST}}^{\prime}(\mathrm{Nei}, 1973), G_{\mathrm{ST}}^{\prime}$, and $D_{\mathrm{EST}}$ were initially calculated to verify consistency across metrics. Because patterns of all estimates were consistent, only $R_{\mathrm{ST}}$ metrics are reported. The clustering model assignment employed in the program STRUCTURE by using a hierarchical approach with the assistance of the web-based software STRUCTURE HARVESTER, vers. 0.6.94 (Earl and vonHoldt, 2012), was used to identify the most appropriate number of distinct populations $(K)$ of each run. Simulations were run by using the locprior parameter, with 5 replicates for each $K$, the length of the burn-in period was 20,000 runs, and the number of Markov chain Monte-Carlo reps after burn-in was 20,000. Sites that were strongly assigned to one population were removed from the data set, and STRUCTURE was run iteratively until $K=1$ was the most appropriate assignment for each cluster. The effective numbers of migrants per generation and year (based on generation time of 5-7 years for cobia) were calculated for each resulting homogenous cluster in Arlequin.

\section{Results}

\section{Tag-recapture data}

The tagging data analyzed covers a 29 -year period, with the first fish tagged in 1988 and the last recapture occurring in 2017. During that period, 25,867 cobia were tagged cumulatively by all 7 tagging programs (Table 1), and 2124 cobia were subsequently recaptured and reported (8\%) with the highest recapture rates occurring in South Carolina (18\%) and Virginia (11\%) and the lowest in the GOM (7\%). After removing recaptures that were missing location or date information $(n=110)$ as well as those that occurred less than $30 \mathrm{~d}$ after tagging $(n=264)$, the combined data set consisted of 1750 recaptures. Mean FL at tagging was largest in Virginia, South Carolina, and North Carolina (Table 3) and was smaller along the coast of Florida and in the GOM. Overall, mean FL at tagging was $786 \mathrm{~mm}$, indicating that most tagging efforts were focused on sublegal cobia because the minimum legal size was $838 \mathrm{~mm}$ FL until September 2017 in federal waters in the western North Atlantic Ocean and until 2016 in North Carolina and Virginia state waters. Minimum legal size in the GOM remains $838 \mathrm{~mm}$ FL. Mean FL at recapture (Table 4) was largest from cobia recaptured in North Carolina, South Carolina, and Virginia but did not vary greatly 


\section{Table 2}

Details about collection of samples of cobia (Rachycentron canadum) captured in the Gulf of Mexico and Atlantic Ocean in the southeastern United States during 2005-2017 and successfully genotyped for inclusion in genetic data analyses. Sample sizes are given for both the initial partitioned data set and the final grouped data set.

\begin{tabular}{|c|c|c|c|c|c|}
\hline \multirow[b]{2}{*}{ Code } & \multirow[b]{2}{*}{ Location } & \multirow[b]{2}{*}{ Collection years } & \multicolumn{2}{|c|}{ Sample size } & \multirow{2}{*}{$\begin{array}{c}\text { Final } \\
\text { group code }\end{array}$} \\
\hline & & & Initial & Final & \\
\hline $\mathrm{TX}$ & Texas (Corpus Christi) & 2010-2011 & 51 & \multirow{6}{*}{385} & \multirow{6}{*}{ GOM } \\
\hline MS & Mississippi & 2010 & 6 & & \\
\hline FLW & Florida panhandle & 2008,2017 & 45 & & \\
\hline FLS & Florida Keys & 2010,2015 & 9 & & \\
\hline FLE1 & Boynton Beach to Jupiter Beach & 2016-2017 & 36 & & \\
\hline FLE2 & Hobe Sound to Ft. Pierce & $2011,2015-2017$ & 238 & & \\
\hline FLE3 & Canaveral/Sebastian & $2014-2017$ & 77 & 77 & FLE3 \\
\hline FLGA & Jacksonville, FL, to Brunswick, GA & $2009-2010,2016-2017$ & 16 & \multirow{2}{*}{50} & \multirow{2}{*}{ FLGA } \\
\hline GA & Savannah & 2008-2009, 2012, 2014-2016 & 34 & & \\
\hline$\overline{\mathrm{SCO} 1}$ & Offshore Port Royal Sound, Betsy Ross Reef & $2009-2016$ & 430 & \multirow{5}{*}{1291} & \multirow{5}{*}{ Atlantic offshore } \\
\hline $\mathrm{SCO} 2$ & Offshore Charleston, Murrels Inlet, Georgetown & 2007-2011, 2015-2017 & 21 & & \\
\hline $\mathrm{SCO}$ & All other SC offshore samples & 2007-2009, 2014-2017 & 615 & & \\
\hline NCO1 & Offshore south of Cape Hatteras & $2010,2013-2014,2016-2017$ & 35 & & \\
\hline NOC2 & Offshore at and north of Cape Hatteras & 2008-2010, 2016-2017 & 190 & & \\
\hline$\overline{\text { SCI }}$ & SC inshore & $2005,2007-2016$ & 834 & 834 & SC inshore \\
\hline $\mathrm{NC1}$ & Inshore area around Cape Lookout & $2010,2016-2017$ & 16 & \multirow{3}{*}{159} & \multirow{3}{*}{ NCVA inshore } \\
\hline NC2 & Inshore area of Pamlico Sound & $2010,2016-2017$ & 41 & & \\
\hline VA & VA inshore & 2006-2008, 2017 & 102 & & \\
\hline
\end{tabular}

from zone to zone. For all cobia recaptures, the mean number of days between initial tagging and recapture (days at large) was $463 \mathrm{~d}$ and varied slightly depending on tagging zone (Table 5). The results from the 4 main tagging zones, Virginia, South Carolina, Brevard County in Florida, and the Florida Keys, generated a large number of recaptures $(n=90-351)$, provided information relevant to assessing the stock boundary between GOM and western North Atlantic Ocean cobia, and are reported herein. The remaining 6 zones provided supplementary data that are reflected in overall summaries of movement. References to the number of cobia tagged in a specific region or time of year will henceforth refer only to tagging events with a subsequent recapture in excess of $30 \mathrm{~d}$.

\section{Virginia}

All cobia in the Virginia zone were tagged within the Chesapeake Bay or immediately adjacent as part of an annual spawning aggregation (Richards, 1967) that occurs during summer $(n=351)$. Peak interactions occur over a relatively brief period, and most fish were captured during JuneAugust, when 91\% ( $n=321)$ of tagging events and 88\% $(n=277)$ of recaptures took place. In contrast, only $1 \%$ $(n=4)$ of cobia tagging events and $2 \%(n=6)$ of recaptures occurred during October-April. Cobia tagged in this zone were largely recaptured in the same zone $(n=293,84 \%)$ in subsequent years and often in close proximity to the tagging location (Fig. 3). There was considerable exchange between the Chesapeake Bay and the North Carolina
Outer Banks, with Chesapeake Bay fish tagged during July-September being recaptured in North Carolina during April-July ( $n=34)$ or October-December $(n=8)$. In total, $95 \%$ of cobia tagged in Virginia were recaptured in the Virginia or North Carolina zones. A similar pattern occurred with cobia tagged off North Carolina, where 86\% $(n=18)$ were eventually recaptured in the Chesapeake Bay. A small subset of cobia tagged in the Chesapeake Bay during summer were also recaptured off the east coast of Florida (north of Brevard/Brevard zones) during late fall-winter $(n=2)$ or spring $(n=6)$. Three cobia were also recaptured in the GOM, after $2-4$ years at large. The furthest of these recaptures represents a movement of at least $2500 \mathrm{~km}$ from the tagging location. Although unexpected, these long distance movements are consistent with genetic data that indicate some level of gene flow between GOM and western North Atlantic Ocean stocks.

\section{South Carolina}

Historically, cobia annually aggregate in 3 South Carolina estuaries, Port Royal, Calibogue, and St. Helena Sounds, along with coastal waters from roughly 0-30 km offshore during April-June. The majority of South Carolina cobia ( $n=128)$ were tagged within Port Royal Sound during these aggregations $(n=112,88 \%)$. Peak interactions in South Carolina coastal waters are brief. Over $90 \%$ of tagging $(n=117)$ and recaptures $(n=111)$ occurred during AprilJuly, whereas only $2 \%(n=2)$ of tagging and $3 \%(n=3)$ of recaptures occurred in October-March. As in Virginia, the 


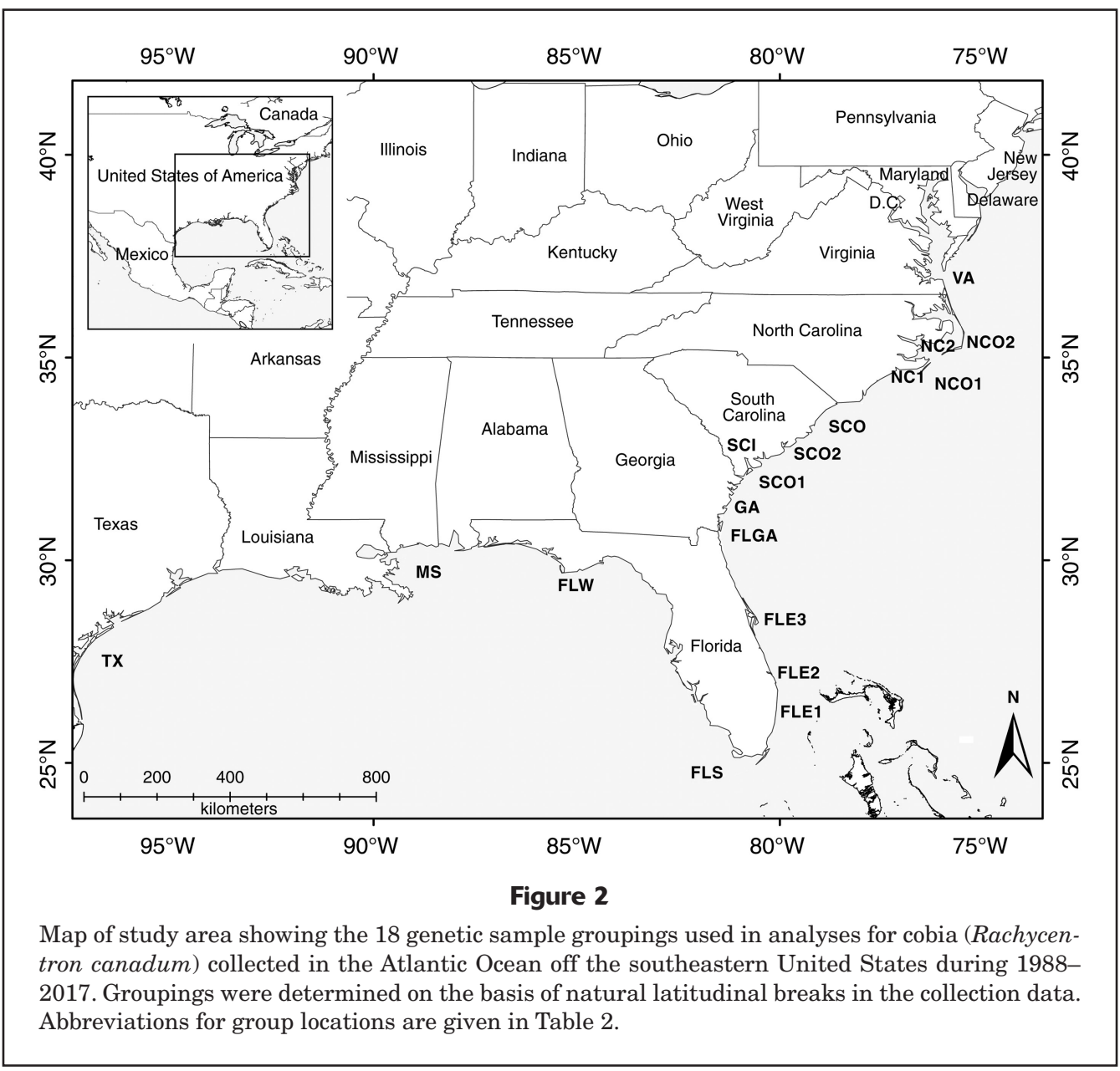

\section{Table 3}

Mean fork length (FL) at tagging, by tagging zone, of cobia (Rachycentron canadum) sampled from 1988 through 2017. The tagging zones of Georgia $(n=1)$ and north of Brevard County, Florida $(n=2)$, were excluded because of small sample sizes. Standard deviations (SDs) are given for means. GOM=Gulf of Mexico.

\begin{tabular}{ll}
\hline Tagging zone & Mean FL (mm) \\
\hline Virginia & $853($ SD 9) \\
North Carolina & 803 (SD 19) \\
South Carolina & 825 (SD 10) \\
Brevard County & 774 (SD 15) \\
South of Brevard & 740 (SD 30) \\
Florida Keys & 750 (SD 6) \\
GOM & 764 (SD 25) \\
Total & 786 (SD 19) \\
\end{tabular}

majority of South Carolina cobia were recaptured within the South Carolina zone $(n=112,87.5 \%)$ in subsequent years and in close proximity to the tagging location (Fig. 3). Cobia tagged in South Carolina were also recaptured off the east coast of Florida (north of Brevard/Brevard),

\section{Table 4}

Mean fork length (FL) at recapture, by recapture zone, of cobia (Rachycentron canadum) sampled from 1988 through 2017. The recapture zones of north of Virginia (sample size $[n]=2)$ and Georgia $(n=5)$ were excluded because of small sample sizes. Standard deviations (SDs) are given for means. GOM=Gulf of Mexico.

\begin{tabular}{lr}
\hline Recapture zone & Mean FL (mm) \\
\hline Virginia & 964 (SD 10) \\
North Carolina & 1008 (SD 29) \\
South Carolina & 985 (SD 13) \\
North of Brevard & 957 (SD 19) \\
Brevard & 921 (SD 21) \\
South of Brevard & 972 (SD 20) \\
Florida Keys & 903 (SD 8) \\
GOM & 935 (SD 6)
\end{tabular}

primarily during November-April ( $n=12)$. In total, $98 \%$ of cobia tagged in South Carolina were recaptured there or in the north of Brevard/Brevard zones. One cobia tagged within Port Royal Sound was recaptured in the GOM off the central coast of Florida after 2 years at large. 


\section{Table 5}

Mean number of days between initial tagging and recapture (days at large), by tagging zone, for cobia (Rachycentron canadum) captured and tagged between 1988 and 2017. Standard deviations (SDs) are given for means. GOM=Gulf of Mexico.

\begin{tabular}{lc}
\hline Tagging zone & Mean days at large \\
\hline Virginia & $539($ SD 25) \\
North Carolina & $766($ SD 190) \\
South Carolina & $496($ SD 33) \\
Brevard County & $400($ SD 38) \\
South of Brevard & $430($ SD 86$)$ \\
Florida Keys & $362($ SD 22) \\
GOM & $449($ SD 13) \\
Total & $464($ SD 10) \\
\end{tabular}

\section{Brevard County, Florida}

Of the 90 recaptures from the Brevard zone, the majority $(n=56,62 \%)$ were tagged during March-April, and $31 \%$ $(n=18)$ of recaptures occurred then as well. However, in contrast to the Virginia and South Carolina zones, cobia were available over a long period, and tagging occurred in every month of the year excluding September. Additionally, recaptures occurred in the Brevard zone during every month of the year. Cobia tagged in the Brevard zone were also recaptured over a very wide geographic area, from Texas to New Jersey, and recaptures of Brevard-tagged cobia occurred in every zone (Fig. 3). Recaptures in the Brevard zone occurred from cobia tagged from Louisiana to Virginia. Unlike in Virginia and South Carolina, where the majority of cobia were recaptured in the same zone where tagging occurred, only $37 \%(n=33)$ of the cobia tagged in the Brevard zone were also recaptured in the Brevard

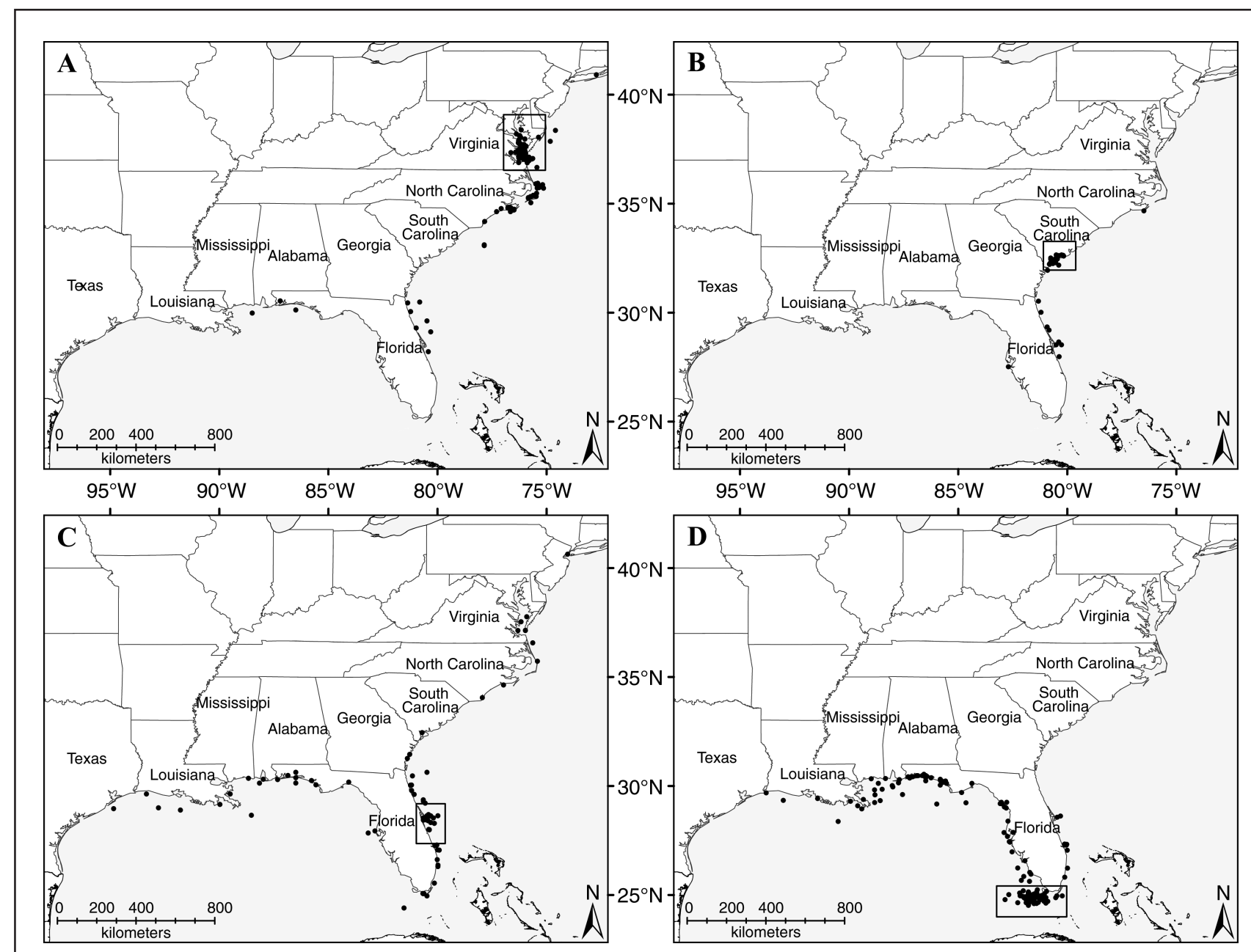

Figure 3

Maps of study area showing the sites where cobia (Rachycentron canadum) were recaptured after being tagged in 1988-2017 in 4 zones: (A) Virginia, including all waters of the Chesapeake Bay, (B) South Carolina, (C) Brevard County, Florida, and (D) Florida Keys. A rectangle indicates the general tagging location in each zone. 
zone. The next largest group of exchange was the GOM, where $22 \% \quad(n=20)$ of recaptures occurred. Cobia tagged in Brevard in January-March were largely recaptured in the GOM during April-May. Exchange also occurred with the south of Brevard and Florida Keys zones $(n=14,16 \%$ collectively), north of Brevard ( $n=10,11 \%)$, and the zones north of the Florida border ( $n=13,14 \%$ collectively).

\section{Florida Keys}

In a pattern similar to that of the Brevard zone, cobia were tagged $(n=181)$ and recaptured during every month of the year in this zone. The majority of tagging events $(n=109,60 \%)$ and recaptures $(n=113,56 \%)$ occurred during December-March. Only 18\% ( $n=32)$ of tagging events and $21 \%(n=43)$ of recaptures occurred during June-October. Most fish tagged in the Florida Keys zone were recaptured in the same zone $(n=104,57 \%)$, often in close proximity to the tagging location (Fig. 3). The next greatest area of exchange was the GOM zone ( $n=66,37 \%)$, with most recaptures occurring during April and May. Conversely, of the 201 cobia recaptured in the Florida Keys zone, $45 \%(n=90)$ were originally tagged in the GOM. Cobia tagged in the Florida Keys zone were recaptured in the GOM from Texas to the west coast of Florida, and recaptures from the Florida Keys and GOM zones collectively account for $94 \%$ of all recaptures for this group. The remaining $6 \%(n=10)$ were recaptured on the east coast of Florida (Brevard/south of Brevard zones). To date, no cobia tagged in the Florida Keys zone have been recaptured north of Cape Canaveral, and no cobia tagged north of Florida on the East Coast have been recaptured in the Florida Keys zone.

\section{Tagging summary}

Cobia tagged in the GOM were captured in the western North Atlantic Ocean $(n=59,6 \%)$ and cobia tagged in the western North Atlantic Ocean were recaptured in the GOM $(n=26,4 \%)$ in relatively small numbers. However, most of this exchange occurred between the GOM and the east coast of Florida. Movements of cobia tagged north of Florida to the GOM $(n=4,0.6 \%)$ and from the GOM to north of Florida $(n=4,0.4 \%)$ were very rare. Movements of fish tagged above the current stock delineation at the border of Florida and Georgia to the north of Brevard and Brevard zones in northern and central Florida $(n=21,4 \%)$ and vice versa $(n=14,14 \%)$ were somewhat more common. Evaluating the frequency of recaptures by recapture location can provide information on the seasonal availability and susceptibility of cobia to the fishery during the period of the study. In the northern area, from Georgia through the Mid-Atlantic region, cobia were mostly recaptured during May-August $(n=434,88 \%)$ with a peak in June $(n=144$, Table 6$)$. In the GOM, cobia were present for a slightly longer period with recaptures mostly occurring between April and September $(n=767,84 \%)$, peaking in April $(n=164)$. In contrast to the areas from Georgia to the north and the GOM, cobia recaptures along the east coast of Florida and the Florida Keys occurred throughout the year, with no clear temporal peaks.

\section{Table 6}

Number of cobia (Rachycentron canadum) recaptured by month from 1988 through 2017 for 3 regions along the southeastern coast of the United States. GOM=Gulf of Mexico.

\begin{tabular}{lrcc}
\hline Month & GOM & $\begin{array}{c}\text { East Florida and } \\
\text { Florida Keys }\end{array}$ & $\begin{array}{c}\text { North of } \\
\text { Florida }\end{array}$ \\
\hline January & 11 & 41 & 2 \\
February & 12 & 39 & 1 \\
March & 28 & 61 & 1 \\
April & 165 & 35 & 18 \\
May & 141 & 24 & 103 \\
June & 139 & 15 & 144 \\
July & 127 & 23 & 112 \\
August & 111 & 20 & 75 \\
September & 85 & 10 & 26 \\
October & 58 & 18 & 7 \\
November & 26 & 20 & 3 \\
December & 11 & 34 & 3 \\
& & & \\
\hline
\end{tabular}

\section{Genetics}

A total of 2796 samples meeting our selection criteria were successfully genotyped for inclusion in data analyses; collection years for samples included 2005 through 2017 (Table 2). Only a single duplicate sample and 39 hatcheryproduced fish occurred within the original data set. No large family groups ( $>3$ siblings) were present within the data set, and only 12 fullsib pairs were identified $(P=1.0)$; therefore, no confounding effects from family structure are anticipated in further analyses.

Results from multiple rounds of hierarchical STRUCTURE, initial pairwise $F_{\mathrm{ST}}$, and HWE analyses support the notion of a genetically distinct South Carolina inshore population and a homogenous GOM population ranging from Texas through the Ft. Pierce, Florida, area (FLE2) (Fig. 4). Additionally, the Virginia and inshore North Carolina (NC1, NC2) samples represented a distinct genetic grouping, as did the combined offshore South Carolina and North Carolina samples (SCO, SCO1, SCO2, NCO1, NCO2) (Fig. 4). Samples from Cape Canaveral, Florida, through Savannah, Georgia, had genetic similarities with samples from collection locations both to the north (SCOs) and to the south (FLE2) and appeared to reflect a geographic transition zone in the STRUCTURE analyses (Fig. 4). As such, the iterative AMOVA were employed to evaluate potential breaks in gene flow within the area, including all potential locations from those of Atlantic Ocean offshore (SCOs, NCOs) and Savannah (GA) samples through those of Jupiter Beach (FLE1) and Hobe Sound (FLE2) in Florida. Results indicate that the strongest significant break $\left(R_{\mathrm{ST}}=0.0073, P=0.001\right)$ among the groupings occurred with the separation between the Cape Canaveral (FLE3) and Jacksonville, Florida/Brunswick, Georgia (FLGA) locations, explaining $0.73 \%$ of the variation in the data set. However, grouping scenarios between 


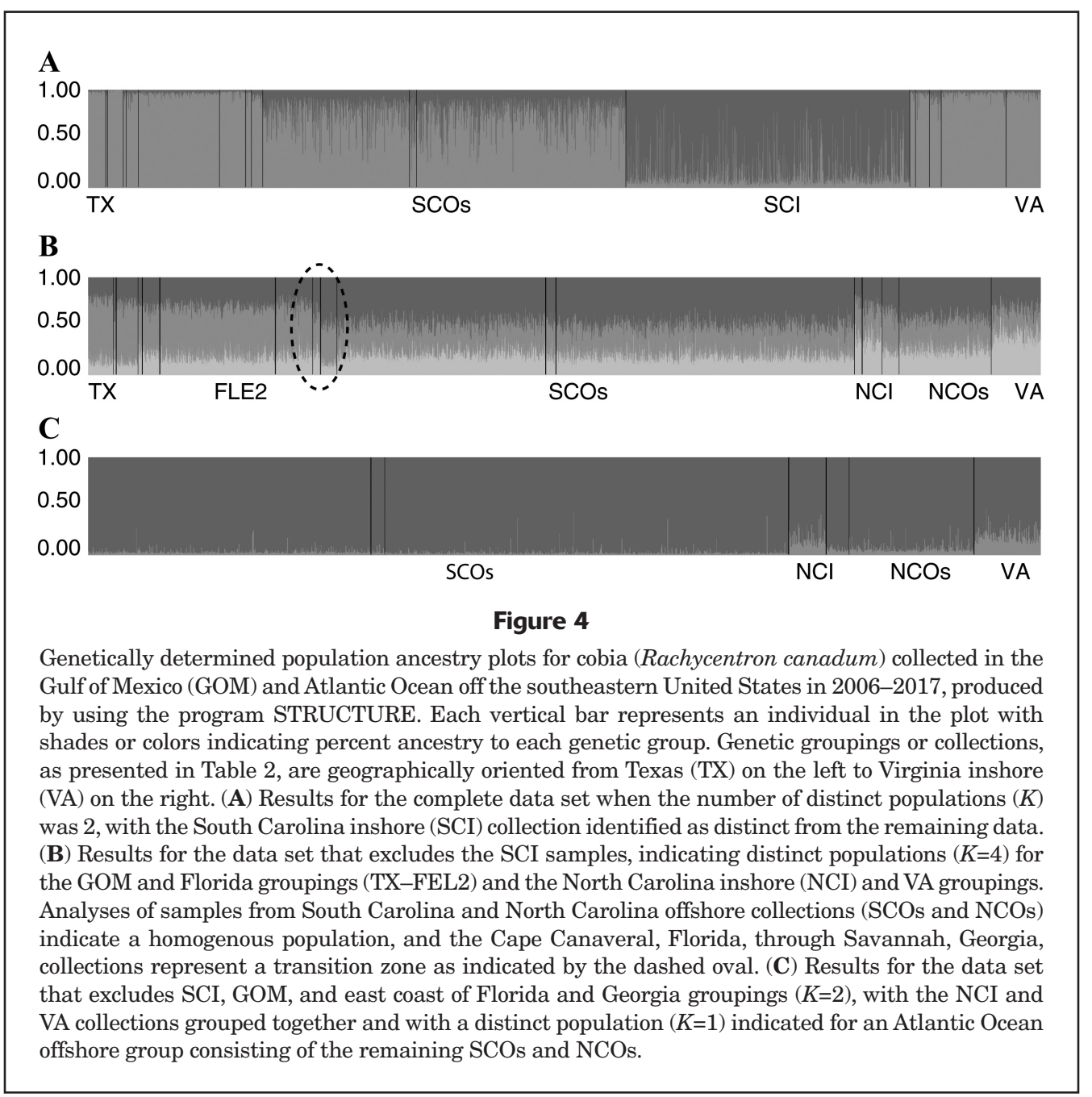

the Atlantic Ocean offshore (SCOs, NCOs) and Savannah (GA) samples, between Savannah (GA) and Jacksonville-Brunswick (FLGA) samples, and between Ft. Pierce (FLE2) and Cape Canaveral (FLE3) samples were also significant but not as strong $\left(R_{\mathrm{ST}}=0.0067-0.0069\right.$, $P=0.004-0.006$ ), explaining $0.67-0.69 \%$ of the variation. The last AMOVA scenario (break between Jupiter Beach and Hobe Sound) did not partition a significant amount of variation among groupings $(P=0.450)$. Therefore, the AMOVA also support the occurrence of a transition zone from Cape Canaveral through Savannah.

Guided by these analyses, final sample groupings included GOM, South Carolina inshore, North CarolinaVirginia inshore, and Atlantic Ocean offshore populations, as well as the Cape Canaveral and Jacksonville-Savannah groupings (Table 2). Due to the lower sample sizes from some of the GOM and North Carolina inshore collection locations, deviations from HWE were evaluated to verify no substructure was being masked within these regions. No loci were out of HWE within the GOM population and only a single locus was out of HWE $(P<0.001)$ in the combined North Carolina inshore and Virginia data set, supporting the groupings. Pairwise comparisons among these groupings confirmed significant differences between all groupings $(P<0.00001-0.04)$, except comparisons with the Cape Canaveral and Jacksonville-Savannah groupings with GOM and Atlantic Ocean offshore populations $(P=0.07-0.96)$. Significant genetic differentiation ranged from an $R_{\mathrm{ST}}$ of 0.020 between South Carolina inshore and GOM populations to an $R_{\mathrm{ST}}$ of 0.006 between the South Carolina inshore and Atlantic Ocean offshore populations (Table 7). The levels of genetic differentiation detected translated into effective number of migrants ranging from 0.2 to 10.0 individuals/year between these populations. Therefore, the results indicate that the cobia stock boundary is occurring somewhere within a range from Cape Canaveral to northern Georgia, a location that is consistent with that of the current management stock boundary along the coast of the southeastern United States.

\section{Discussion}

A few major patterns became apparent when tagging data were evaluated together. Cobia in the area north of Florida were seasonally available as a pulse fishery in close proximity 


\section{Table 7}

Ranked $R_{\mathrm{ST}}$ values from significant pairwise comparisons among final genetic sample groupings of cobia (Rachycentron canadum) with effective number of migrants $\left(\mathrm{N}_{\mathrm{em}}\right)$. Annual calculations are based on a generation time of 5-7 years. Examined regions include South Carolina inshore (SC inshore), North Carolina-Virginia inshore (NCVA inshore), Gulf of Mexico (GOM), Jacksonville, Florida, and Savannah, Georgia (FLGA), Cape Canaveral, Florida (FLE3), and Atlantic Ocean offshore.

\begin{tabular}{|c|c|c|c|}
\hline Pairwise comparison & $R_{\mathrm{ST}}$ & $\begin{array}{c}\mathrm{N}_{\mathrm{em}} \text { per } \\
\text { generation }\end{array}$ & $\begin{array}{c}\mathrm{N}_{\text {em }} \text { per } \\
\text { year }\end{array}$ \\
\hline SC inshore-GOM & 0.020 & 1.0 & $0.2-0.6$ \\
\hline SC inshore-NCVA inshore & 0.019 & 12.9 & $1.8-2.6$ \\
\hline SC inshore-FLE3 & 0.015 & 20.5 & $2.9-4.2$ \\
\hline NCVA inshore-GOM & 0.012 & 20.6 & $2.9-4.1$ \\
\hline NCVA inshore-FLGA & 0.011 & 22.5 & $3.2-4.5$ \\
\hline NCVA inshore-FLE3 & 0.009 & 27.5 & $3.9-5.5$ \\
\hline SC inshore-FLGA & 0.009 & 27.5 & $3.9-5.5$ \\
\hline Atlantic offshore-GOM & 0.007 & 35.5 & $5.1-7.1$ \\
\hline SC inshore-Atlantic offshore & 0.006 & 41.4 & $5.9-8.3$ \\
\hline $\begin{array}{l}\text { NCVA inshore-Atlantic } \\
\text { offshore }\end{array}$ & 0.005 & 49.8 & $7.1-10.0$ \\
\hline
\end{tabular}

to the coast during spring and summer and are largely absent from harvest during cooler months. One group of cobia moves through coastal North Carolina waters in May-June and in October on their way to and from the Chesapeake Bay, although some cobia aggregate in North Carolina estuaries as well (Smith, 1995). Another group moves into the southern estuaries of South Carolina during May and June. Higher recapture rates in the Chesapeake Bay and South Carolina estuaries indicate that fish remain within these systems for extended periods of time and may have historically been subject to higher fishing pressure than other areas, such as the GOM, where recapture rates are lower. There is evidence of some exchange between cobia tagged in South Carolina and Virginia with the central and northeast coast of Florida, indicating that some level of seasonal migration from south to north occurs. However, Hendon and Franks ${ }^{3}$ described potential inshore-offshore seasonal movements in the northern GOM, and the authors believe inshore-offshore movements occur in the western North Atlantic Ocean as well. A movement from estuarine or nearshore environments to deeper, warmer offshore waters in winter may explain why so few fish tagged in either South Carolina or Virginia are recaptured in other zones and are so frequently recaptured in the same locations in subsequent years. Cobia moving into deeper waters may be subject to reduced fishing pressure and therefore less likely to be recaptured until seasonally moving back into natal estuaries or nearshore waters where more concentrated fishing effort occurs. Commercial catch data (Wrege ${ }^{7}$ )

\footnotetext{
${ }^{7}$ Wrege, B. M. 2018. Spatial and temporal distribution of cobia, Southeast US and Gulf of Mexico. SEDAR58-SID-10, 18 p. Southeast Data Assessment and Review (SEDAR), North Charleston, SC. [Available from website.]
}

and pop-up satellite archival tagging data (Jensen and Graves $^{8}$ ) provide evidence that cobia are present on the continental shelf waters of North Carolina, South Carolina, Georgia, and north Florida in winter. Additionally, cobia fitted with acoustic transmitters in South Carolina and Georgia were completely absent from detection in coastal receiver arrays in winter (Young et al. ${ }^{9}$ ), indicating movement into other areas (i.e., deeper water).

There is strong evidence that some cobia use the areas along the east coast of Florida and the Florida Keys as overwintering locations before undertaking a seasonal migration into the GOM during spring and summer, as also reported by Dippold et al. (2017). To a lesser extent, a similar migration occurs between central and north Florida to the north as described above. However, there is evidence that some cobia may be largely resident to these locations throughout the year. Many cobia tagged in winter have been recaptured in the same zone in summer and vice versa, representing fish that are not likely undertaking a seasonal migration to the GOM or north along the Atlantic coast.

Although it has been speculated that the Florida Keys serve as an overwintering location for both western North Atlantic Ocean and GOM cobia and a boundary between the 2 stocks, the available genetic and tagging data do not support that conclusion. A segment of the GOM cobia stock does appear to overwinter in the Florida Keys and migrate into the northern GOM during spring. However, despite movement into southeast and central Florida, no cobia tagged in the Florida Keys were recaptured north of Cape Canaveral. Franks et al. (1991), Hammond ${ }^{10}$, and Dippold et al. (2017) describe routine movements of cobia between the GOM and western North Atlantic Ocean. However, virtually all of these movements occurred between the GOM and the southeast and central coasts of Florida. This finding is supported by the results of the genetic analysis, indicating that cobia collected from the Florida Keys and southeast coast of Florida were genetically similar to those collected throughout the GOM. Analyses of our robust microsatellite data set indicates that a genetic break occurs somewhere between Cape Canaveral and northern Georgia. Tagging results indicate that cobia tagged near Cape Canaveral distribute widely to both the GOM and north of Florida, with greater dispersal to the GOM. These results indicate that the area around Cape Canaveral serves as a transitional area for GOM and western North Atlantic Ocean cobia. Although we are confident

\footnotetext{
8 Jensen, D., and J. Graves. 2018. Use of pop-up satellite archival tags (PSATs) to investigate the movements, habitat utilization and post-release survival of cobia (Rachycentron canadum) that summer in Virginia waters. SEDAR58-SID-02, 12 p. Southeast Data Assessment and Review (SEDAR), North Charleston, SC. [Available from website.]

9 Young, J., M. Perkinson, K. Brenkert, E. Reyier, and J. Whittington. 2018. Cobia telemetry working paper. SEDAR58-SID-08, 15 p. Southeast Data Assessment and Review (SEDAR), North Charleston, SC. [website.]

${ }^{10}$ Hammond, D. L. 2001. Status of the South Carolina fisheries for cobia. South Carolina Dep. Nat. Resour., Mar. Resour. Div., Tech. Rep. 89, 22 p.
} 
that Cape Canaveral falls within this transitional area, genetic and tag-recapture data for northern Florida and Georgia are limited, making it difficult to determine how far this transition extends to the north.

The area around Cape Canaveral is a well-studied phylogeographic break for many species (Burton, 1998; Hellberg et al., 2002). Species that either terminate their southern range or show a divergence in genetics in this area include the Eastern oyster (Crassostrea virginica) (Reeb and Avise, 1990), Atlantic menhaden (Brevoortia tyrannus) and black sea bass (Centropristis striata) (Bowen and Avise, 1990), and American horseshoe crab (Limulus polyphemus) and oyster toadfish (Opsanus tau) (Avise, 1992). The region marks the transition from a temperate to a subtropical climate where the Gulf Stream diverges from the coastline (Avise, 1992), with potential implications for the distribution of eggs and larvae. Differences in water temperature between the areas north and south of Cape Canaveral may also have an impact on the migratory behavior of cobia. Oceanographic temperature data from the NOAA National Data Buoy Center indicate that the coastal waters at and just north of Cape Canaveral are the southernmost location along the U.S. Atlantic coast where coastal mean water temperatures routinely fall below $20^{\circ} \mathrm{C}$ during winter. The waters offshore or south of Cape Canaveral through the Florida Keys typically remain above $20^{\circ} \mathrm{C}$ throughout the year. These moderate winter water temperatures may explain why some cobia in these waters do not appear to make long migrations and may be found there year-round. By contrast, coastal waters north of Cape Canaveral regularly fall below $20^{\circ} \mathrm{C}$ and result in the movement of cobia into more southerly waters, deeper waters, or a combination of both.

The transitional area occurring within the range of Cape Canaveral to northern Georgia appears to serve as a major division between GOM and western North Atlantic Ocean stocks. The complete population structure and migratory patterns of GOM and Atlantic Ocean cobia is likely more complex. Tag-recapture data indicate multiple migratory behaviors and geographic partitioning of cobia in the Atlantic Ocean group underscored by the lack of exchange between cobia tagged in Virginia or North Carolina and cobia tagged in South Carolina. Hendon and Franks ${ }^{3}$ suggested multiple migratory patterns from cobia tagged in the GOM as well. These complicated migratory patterns are further supported by genetic analysis. Darden et al. (2014) found evidence of distinct population segments within the western North Atlantic Ocean stock. Although our study found no genetic differences throughout the GOM stock, increased sample sizes in the Florida Keys and northern GOM locations could potentially provide greater resolution into the genetic population structure of cobia in these areas. Current projects that use acoustic and satellite telemetry, as well as additional genetic and conventional tagging data, when evaluated in concert, will increase our understanding of cobia structure on a regional level and benefit the assessment and management process moving forward.

\section{Acknowledgments}

We wish to thank the late K. Burns whose tagging data was integral to these analyses and the Mote Marine Laboratory for allowing their inclusion. We also thank the Hilton Head Reef Foundation, S. Poland at the North Carolina Division of Marine Fisheries, contributing anglers, and the NOAA Hollings Marine Laboratory. Funding for the analyses included South Carolina Saltwater Recreational License Funds and NOAA CRP project NA15NMF4540105. This manuscript represents SCDNR MRRI contribution number 807.

\section{Literature cited}

Avise, J. C.

1992. Molecular population structure and the biogeographic history of a regional fauna: a case history with lessons for conservation biology. Oikos 63:62-76. Crossref

Begg, G. A., and J. R. Waldman.

1999. An holistic approach to fish stock identification. Fish. Res. 43:35-44. Crossref

Begg, G. A., D. S. Cameron, and W. Sawynok.

1997. Movements and stock structure of school mackerel (Scomberomorus queenslandicus) and spotted mackerel (S. munroi) in Australian east-coast waters. Mar. Freshw. Res. 48:295-301. Crossref

Bielawski, J. P., and D. E. Pumo.

1997. Randomly amplified polymorphic DNA (RAPD) analysis of Atlantic Coast striped bass. Heredity 78:32-40. Crossref

Biesiot, P. M., R. E. Caylor, and J. S. Franks.

1994. Biochemical and histological changes during ovarian development of cobia, Rachycentron canadum, from the northern Gulf of Mexico. Fish. Bull. 92:686-696.

Bowen, B. W., and J. C. Avise.

1990. Genetic structure of Atlantic and Gulf of Mexico populations of sea bass, menhaden, and sturgeon: influence of zoogeographic factors and life-history patterns. Mar. Biol. 107:371-381. Crossref

Briggs, J. C.

1960. Fishes of worldwide (circumtropical) distribution. Copeia 1960:171-180.

Burton, R. S.

1998. Intraspecific phylogeography across the Point Conception biogeographic boundary. Evolution 52:734-745. Crossref

Cadrin, S. X., K. D. Friedland, and J. R. Waldman (eds.).

2005. Stock identification methods: applications in fishery science, 736 p. Elsevier, Burlington, MA.

Campbell, M. R., C. C. Kozfkay, T. Copeland, W. C. Schrader, M. W. Ackerman, and S. R. Narum.

2012. Estimating abundance and life history characteristics of threatened wild Snake River steelhead stocks by using genetic stock identification. Trans. Am. Fish. Soc. 141:1310-1327. Crossref

Darden, T. D., M. J. Walker, K. Brenkert, J. R. Yost, and M. R. Denson.

2014. Population genetics of Cobia Rachycentron canadum: implications for fishery management along the coast of the southeastern United States. Fish. Bull. 112:24-35.

Dippold, D. A., R. T. Leaf, J. S. Franks, and J. R. Hendon.

2017. Growth, mortality, and movement of cobia (Rachycentron canadum). Fish. Bull. 115:460-472. Crossref 
Ditty, J. G., and R. F. Shaw.

1992. Larval development, distribution, and ecology of cobia Rachycentron canadum (Family: Rachycentridae) in the northern Gulf of Mexico. Fish. Bull. 90:668-677.

Earl, D. A., and B. M. vonHoldt.

2012. STRUCTURE HARVESTER: a website and program for visualizing STRUCTURE output and implementing the Evanno method. Conserv. Genet. Resour. 4:359-361. Crossref

Excoffier, L., and H. E. L. Lischer.

2010. Arlequin suite ver 3.5: a new series of programs to perform population genetics analyses under Linux and Windows. Mol. Ecol. Resour. 10:564-567. Crossref

Flannery, B. G., R. E. Spangler, B. L. Norcross, C. J. Lewis, and J. K. Wenburg.

2013. Microsatellite analysis of population structure in Alaska eulachon with application to mixed-stock analysis. Trans. Am. Fish. Soc. 142:1036-1048. Crossref

Franks, J. S., and N. J. Brown-Peterson. 2002. A review of age, growth, and reproduction of cobia, Rachycentron canadum, from U.S. waters of the Gulf of Mexico and South Atlantic Ocean. Proc. Gulf Caribb. Fish. Inst. 53:553-569.

Franks, J. S., M. H. Zuber, and T. D. McIlwain.

1991. Trends in seasonal movements of cobia Rachycentron canadum tagged and released in the northern Gulf of Mexico. J. Miss. Acad. Sci. 36(1):55.

GMFMC and SAFMC (Gulf of Mexico and South Atlantic Fishery Management Councils).

1983. Fishery management plan for coastal migratory pelagic resources in the Gulf of Mexico and South Atlantic Region, 311 p. Gulf Mex. Fish. Manage. Counc., Tampa, FL, and South Atl. Fish. Manage. Counc., North Charleston, SC.

2011. Final amendment 18 to the fishery management plan for coastal migratory pelagic resources in the Gulf of Mexico and Atlantic Region including environmental assessment, regulatory impact review, and regulatory flexibility act analysis, 373 p. Gulf Mex. Fish. Manage. Counc., Tampa, FL, and South Atl. Fish. Manage. Counc., North Charleston, SC.

2014. Final amendment 20B to the fishery management plan for the coastal migratory pelagic resources in the Gulf of Mexico and Atlantic Region including environmental assessment, fishery impact statement, regulatory impact review, and regulatory flexibility act analysis, $258 \mathrm{p}$. Gulf Mex. Fish. Manage. Counc., Tampa, FL, and South Atl. Fish. Manage. Counc., North Charleston, SC.

Hansen, L. P., and J. A. Jacobson.

2003. Origin and migration of wild and escaped farmed Atlantic salmon, Salmo salar L., in oceanic areas north of the Faroe Islands. ICES J. Mar. Sci. 60:110-119. Crossref

Hassler, W. W., and R. P. Rainville.

1975. Techniques for hatching and rearing cobia, Rachycentron canadum, through larval and juvenile stages. Univ. N.C. Sea Grant Coll. Program Rep. UNC-SG-75-30, 26 p. Sea Grant, Raleigh, NC.

Hellberg, M. E., R. S. Burton, J. E. Neigel, and S. R. Palumbi. 2002. Genetic assessment of connectivity among marine populations. Bull. Mar. Sci. 70(Suppl. 1):273-290.

Hilborn, R., and C. J. Walters (eds.).

1992. Quantitative fisheries stock assessment: choice, dynamics and uncertainty, 570 p. Chapman and Hall, New York.

Hrincevich, A. W.

1993. Mitochondrial DNA analysis of cobia Rachycentron canadum population structure using restriction fragment length polymorphisms and cytochrome $B$ sequence variation. M.S. thesis, 91 p. Univ. South. Miss., Hattiesburg, MS
Izzo, C., T. M. Ward, A. R. Ivey, I. M. Suthers, J. Stewart, S. C. Sexton, and B. M. Gillanders.

2017. Integrated approach to determining stock structure: implications for fisheries management of sardine, Sardinops sagax, in Australian waters. Rev. Fish Biol. Fish. 27:267-284. Crossref

Jones, O. R., and J. Wang.

2010. COLONY: a program for parentage and sibship inference from multilocus genotype data. Mol. Ecol. Resour. 10:551-555. Crossref

Kalinowski S. T., M. L. Taper, and T. C. Marshall.

2007. Revising how the computer program CERVUS accommodates genotyping error increases success in paternity assignment. Mol. Ecol. 16:1099-1106. Crossref

Knutsen, H., E. M. Olsen, P. E. Jorde, S. H. Espeland, C. André, and N. C. Stenseth.

2011. Are low but statistically significant levels of genetic differentiation in marine fishes 'biologically meaningful'? A case study of coastal Atlantic cod. Mol. Ecol. 20:768-783. Crossref

Lefebvre, L. S., and M. R. Denson.

2012. Inshore spawning of cobia (Rachycentron canadum) in South Carolina. Fish. Bull. 110:397-412.

MSFCMA (Magnuson-Stevens Fishery Conservation and Management Act).

2007. Public Law 94-265. [Available from website.]

Nei, M.

1973. Analysis of gene diversity in subdivided populations. Proc. Natl. Acad. Sci. U.S.A. 70:3321-3323. Crossref

Neilson, J. D., W. T. Stobo, and P. Perley.

2006. Pollock (Pollachius virens) stock structure in the Canadian Maritimes inferred from mark-recapture studies. ICES J. Mar. Sci. 63:749-765. Crossref

Orbesen E. S., J. P. Hoolihan, J. E. Serafy, D. Snodgrass, E. M. Peel, and E. D. Prince.

2008. Transboundary movement of Atlantic istiophorid billfishes among international and US domestic management areas inferred from mark-recapture studies. Mar. Fish. Rev. 70(1):14-23.

Parker, R. W., K. N. Paige, and A. L. Devries.

2002. Genetic variation among populations of the Antarctic toothfish: evolutionary insights and implications for conservation. Polar Biol. 25:256-261.

Peakall, R., and P. E. Smouse.

2006. GENALEX 6: genetic analysis in Excel. Population genetic software for teaching and research. Mol. Ecol. Notes 6:288-295. Crossref

2012. GenAlEx 6.5: genetic analysis in Excel. Population genetic software for teaching and research-an update. Bioinformatics 28:2537-2539. Crossref

Pritchard, J. K., M. Stephens, and P. Donnelly.

2000. Inference of population structure using multilocus genotype data. Genetics 155:945-959.

Renshaw, M. A., E. Saillant, S. C. Bradfield, and J. R. Gold.

2006. Microsatellite multiplex panels for genetic studies of three species of marine fishes: red drum (Sciaenops ocellatus), red snapper (Lutjanus campechanus), and cobia (Rachycentron canadum). Aquaculture 253:731-735. Crossref

Reeb, C. A., and J. C. Avise.

1990. A genetic discontinuity in a continuously distributed species: mitochondrial DNA in the American oyster, Crassostrea virginica. Genetics 124:397-406.

Richards, C. E.

1967. Age, growth and fecundity of the cobia, Rachycentron canadum, from Chesapeake Bay and adjacent Mid-Atlantic waters. Trans. Am. Fish. Soc. 96:343-350. Crossref 
Ricker, W. E.

1948. Methods of estimating vital statistics of fish populations, 115 p. Indiana Univ. Publ., Bloomington, IN.

Saitoh, K.

1998. Genetic variation and local differentiation in the Pacific cod Gadus macrocephalus around Japan revealed by mtDNA and RAPD markers. Fish. Sci. 64:673-679. Crossref SEDAR (Southeast Data Assessment and Review).

2013a. SEDAR 28-Gulf of Mexico cobia stock assessment report, 616 p. SEDAR, North Charleston, SC. [Available from website.]

2013b. SEDAR 28-South Atlantic cobia stock assessment report, 420 p. [Available from website.]
Shaffer, R. V., and E. L. Nakamura.

1989. Synopsis of biological data on the cobia Rachycentron canadum (Pisces: Rachycentridae). NOAA Tech. Rep. NMFS 82 [FAO Fish. Synop. 153], 21 p.

Smith, J. W

1995. Life history of cobia, Rachycentron canadum (Osteichthyes: Rachycentridae), in North Carolina waters. Brimleyana $23: 1-23$.

Williams, E. H.

2001. Assessment of cobia, Rachycentron canadum, in the waters of the U.S. Gulf of Mexico. NOAA Tech. Memo. NMFS-SEFSC-469, 55 p. 